\title{
Rapid Determination of REEs, PGEs, and Other Trace Elements in Geological and Environmental Materials by High Resolution Inductively Coupled Plasma Mass Spectrometry
}

\author{
M. Satyanarayanan*, V. Balaram, S.S. Sawant, K.S.V. Subramanyam, G. Vamsi Krishna, \\ B. Dasaram, and C. Manikyamba \\ CSIR-National Geophysical Research Institute, Hyderabad-500007, India
}

\begin{abstract}
Methodologies were designed and developed using magnetic sector high resolution inductively coupled plasma mass spectrometry (HR-ICP-MS) for the fast, reliable, and accurate determination of different sets of geochemically significant trace elements (at sub-ng/g to $\mu \mathrm{g} / \mathrm{g}$ levels) including rare earth elements (REEs) and platinum group elements (PGEs) in a variety of geological materials for their application in advanced geochemical studies. In the case of trace elements (including REE) in rock, mineral, soil, and sediment samples, about $50 \mathrm{mg}$ each of the samples was dissolved in Savillex ${ }^{\circledR}$ pressure decomposition vessels by utilizing a mix of hydrofluoric-nitricperchloric acids. Procedural blanks were prepared in a similar way. Trace elements were determined in water samples directly after filtration, acidification, and appropriate dilution with ${ }^{129} \mathrm{Xe}$ and ${ }^{132} \mathrm{Xe}$ as the internal standards. NiS fire assay and Te co-precipitation methods were used for the separation and pre-concentration of the PGEs and Au from the rock matrix ( 10 g properly homogenized samples) before their determination by HR-ICP-MS.
\end{abstract}

Synthetic multi-element solutions $(1,10$, and $100 \mathrm{ng} / \mathrm{mL}$ ) were used for the preparation of calibration graphs. In order to validate these methods, a series of international geo-standards starting from acidic to ultra-basic rock, soil, sediment, stream sediment, and water reference samples were analyzed after optimizing the instrumental parameters. Most spectroscopic interferences were removed by choosing optimum resolution (300R) settings for each element or group of elements for the separation of the interfering peaks, such as doubly charged ions and polyatomic species, from the analyte peaks of interest. The matrix effects were minimized by analyzing very diluted samples. Extremely close agreement was found between the data sets by HR-ICP-MS with certified values wherever data available for comparison. The precisions obtained in this study were $<2 \%$ RSD for the majority of elements with comparable accuracy, confirming that the methodologies designed and developed in this study are suitable for obtaining precise data suitable for high precision geochemical, mineral exploration, and environmental studies.

materials such as rocks, minerals, soils, sediments, and water at very low concentrations would help in understanding the composition of the earth and its genesis as a whole. The developments in analytical instrumentation, methodology, and conceptual breakthroughs have made geochemistry a powerful tool to work across the entire spectrum of the earth sciences, including mineral exploration and environmental sciences. Geochemical investigations were also valuable in sustainable mineral exploration and proper management of our environment. Water is an essential component for life on earth and an important source of intake of trace elements for humans. Unfortunately, most of the fresh water bodies all over the world are getting contaminated due to natural and anthropogenic activities, seriously affecting the quality of ground and surface waters. Hence, chemical analysis of water is very important for monitoring the levels of different toxic elements and their source.

One of the exciting frontiers of analytical geochemistry was the ability to analyze elemental and isotopic abundances in different types of geological and environmental materials at previously unattainable precision and spatial resolution. The concentrations of some trace elements, including rare earth elements (REEs), in different types of rocks were not influenced by secondary processes and carry strong signatures of primary process and genetic history of these rocks. Hence, the accurate determination of these trace and ultra-trace elements in a variety of rock samples is extremely important for both basic and applied geochemical studies. In the past, several procedures have been designed and developed by using inductively coupled plasma quadrupole mass spectrometry (ICP-QMS) for the
*Corresponding author.
E-mail: msnarayanan @ngri.res.in

Tel: +91 4027012498 
generation of geochemical data for several trace elements (even at $<1 \mathrm{ng} / \mathrm{g}$ ) in rocks, ores, and minerals with greater precision and accuracy at natural abundance levels (1-6) and includes the following groups of elements: REEs, large ion-lithophile elements (LILEs, e.g., $\mathrm{Rb}$ and $\mathrm{Cs}$ ), high field strength elements (HFSEs, e.g., Ta, Nb, Hf, and $\mathrm{Zr}$ ), platinum group elements (PGEs), gold and its pathfinder elements (e.g., As, Se, and Te).

The majority of published works related to the analysis of geological and environmental materials to date has been by quadrupole instrumentation (QMS). A less attractive feature of ICP-QMS was the less than optimum signal stability over a reasonably short time, typically $1-5 \%$ RSD (7). The origin of instability has several sources such as flicker in plasma, changes in nebulization efficiency, and variations in the plasma tail from where the ions are sampled. The signal stability can be increased significantly by measuring intensity ratios to an internal standard, provided that sequential measurements of the analyte and internal standard were performed within a short time span (8). Despite the excellent performance of ICP-QMS in resolving some of these issues, the technique suffered from its limited capability to resolve spectroscopic interferences. In subsequent years, several other popular mass spectroscopic techniques have entered the arena for elemental analysis which use ICP as an ion source and include ICP-time of flight mass spectrometry (ICP-TOFMS) $(9,10)$, simultaneous magnetic sector ICP-MS (11), and ICP-high resolution magnetic sector-MS (HRICP-MS) $(12,13)$. Of these three approaches, HR-ICP-MS has gained confidence especially by the geological community due to its capability to clearly resolve several spectroscopic interferences and offering extremely high sensitivity. This instrument can be utilized in high-resolution mode to resolve even most complex interferences (14) or even at lower resolution to provide extremely low detection limits. Current HR-ICP-MS instruments have resolving powers up to 10,000 and were typically operated at preset resolution settings for low, medium, or high (15).

The present study demonstrates the capability of HR-ICP-MS for the rapid and accurate determination of geochemically significant groups of trace elements such as LILEs, HFSEs, REEs, PGEs, etc., in varied types of geological samples including water for trace element geochemical, mineral exploration, and environmental studies. An attempt is also made here to describe various related issues such as sample dissolution, matrix interferences, resolution of spectroscopic interferences, linear dynamic range of the calibration curves for different elements, accuracy, and precision.

\section{EXPERIMENTAL}

\section{Instrumentation}

The AttoM ${ }^{\circledR}$ HR-ICP-MS is a double-focusing single-collector instrument with forward Nier-Johnson analyzer geometry (Nu Instruments, UK) and was used in low-resolution mode with the detector in automatic mode. The intensity of the incoming signal triggers acquisition through ion counters, attenuation grid or Faraday cup, thereby dynamically measuring a range of ions. The facility with other logistics available at CSIR-National Geophysical Research Institute (Hyderabad, India) was used for data acquisition. The scanning of ions of particular $\mathrm{m} / \mathrm{z}$ was done in jump-wiggle mode (similar to peak hopping) which permits the analytes of interest to be measured accurately. The sample introduction consisted of a standard Meinhard ${ }^{\circledR}$ nebulizer with a cyclonic spray chamber housed in the Peltier cooling system. The temper- ature was set at $5{ }^{\circ} \mathrm{C}$ to maintain uniformity in sample viscosity and solution density ensuring relatively constant spinning of the solution inside the spray chamber irrespective of the initial condition of the diluted sample. All quantitative measurements were performed using the AttoLab ${ }^{\circledR}$ instrument software, while the data processing was carried out using Nu Quant ${ }^{\circledR}$, (Nu Instruments, UK) which uses knowledge-driven routines in combination with numerical calculations (quantitative analysis) to perform an automated/manual interpretation of the spectrum of interest. The oxide and hydroxide formation levels were low $(<0.2 \%)$ and the doubly charged ions ratio was $<3 \%$. Mass bias fractionation and several well-known isobaric interferences were eliminated by operating the instrument at 300 resolution (300R). The ICP source uses a solid-state $1.6 \mathrm{KW}$ RF generator operating at $27.12 \mathrm{MHz}$. The software performs RF matching and tuning of the torch box, providing simplicity and reliability of the matching system. Mass flow controllers were used for providing stable plasma gas control. The standard plasma torch utilized was of a Fassel design with a $1.5-\mathrm{mm}$ injector. The spray chamber system consists of a cyclonic Peltier-cooled spray chamber system, along with a glass concentric nebulizer with a $0.2-\mathrm{mL} / \mathrm{min}$ uptake rate. Platinumtipped skimmer and sampler cones were used. A three-channel, built-in peristaltic pump was used for pumping the sample solutions and also for draining waste from the spray chamber. The operating parameters (Table I) such as lens voltages, argon flow rate, forward and reflected power of the generator were accurately optimized to obtain maximum sensitivity which would contribute to the quality of the measurements. For further details concerning the instrument, see reference (16). 
For ICP-QMS measurements, a PerkinElmer $^{\circledR}$ ELAN $^{\circledR}$ DRC $^{\text {TM }}$ II ICPmass spectrometer (PerkinElmer, Inc., Shelton, CT, USA) was used. The sample introduction system consisted of a standard Meinhard nebulizer with a cyclonic spray chamber. All quantitative and semiquantitative measurements were performed using instrument software. Several well-known isobaric interferences are programmed and the corrections are automatically applied. The instrumental and data acquisition parameters are listed in reference (4).

\section{Materials and Reagents}

Savillex ${ }^{\circledR}$ pressure decomposition vessels $(60 \mathrm{~mL})$ (Savillex Corporation, Minnetonka, MN, USA) were used for the sample dissolutions. Electronic grade $\mathrm{HF}$, analytical reagent (AR) grade $\mathrm{HClO}_{4}$, distilled $\mathrm{HNO}_{3}$ and $\mathrm{HCl}$, and lithium metaborate (AR grade) were used for sample preparation. A muffle furnace (M/s Krishna Enterprises, India), constructed with silicon carbide tiles and Kanthal heating elements held in ceramic tubes with digital temperature controller (maximum temperature up to $1150{ }^{\circ} \mathrm{C}$ ), was used for fusion. A Millipore ${ }^{\circledR}$ vacuum pump and an all-glass filtration assembly was used for filtering the solutions through $0.45-\mu \mathrm{m}$ cellulose nitrate membrane filters ( 47 mm dia.). Ni powder (-100 mesh) of 99.999\% purity (5N purity, Aldrich Chemical Company Inc., USA) and fire-clay crucibles (Southern Graphite Crucible Works, Salem, Tamil Nadu, India), were used. Milli-Q ${ }^{\circledR}$ water (18 M $\Omega$ ) (Millipore Corporation, USA) was used throughout the analysis. Single and multi-element solutions $(50 \mu \mathrm{g} / \mathrm{mL})$ were obtained from LGC Standards, Germany.

TABLE I

Operating Parameters for HR-ICP-MS Measurements

\begin{tabular}{ll}
\hline Resolution & $300 \mathrm{~m} / \Delta \mathrm{m}$ \\
RF Power & $1300 \mathrm{~W}$ \\
Reflected Power & $<3 \mathrm{~W}$ \\
Coolant argon flow & $15.0 \mathrm{~L} / \mathrm{min}$ \\
Auxiliary argon flow & $0.9 \mathrm{~L} / \mathrm{min}$ \\
Sample argon flow & $1.076 \mathrm{~L} / \mathrm{min}$ \\
Extraction lens voltage & $2990 \mathrm{~V}$ \\
Focus lens voltage & $4313 \mathrm{~V}$ \\
Sample cone & $1.1 \mathrm{~mm}$ orifice, Pt-tipped \\
Skimmer cone & $0.7 \mathrm{~mm}$ orifice, Pt-tipped \\
Sample uptake rate & $0.8 \mathrm{~mL} / \mathrm{min}$ pumping via a peristaltic pump \\
Sample introduction & Automated via a Cetac Technologies auto- \\
& sampler \\
Detector & Dual mode with SEM and faraday cup \\
Instrument tuning & Performed using $1 \mathrm{ng} / \mathrm{mL}$ multi-element \\
Sensitivity & (Li, Be, Mg, Sc, Co, Y, In, Cs, Tb, Tm, Pb, U) \\
Scan type & $1 \times 10^{6}$ with 115 In and 2.3x106 with $238 \mathrm{U}$ \\
Ion lens setting & Magnet jumping with electric scan over a \\
& small mass range (Jump wiggle) \\
& Optimized in order to obtain maximum \\
& signal sensitivity and resolution peaks \\
\hline
\end{tabular}

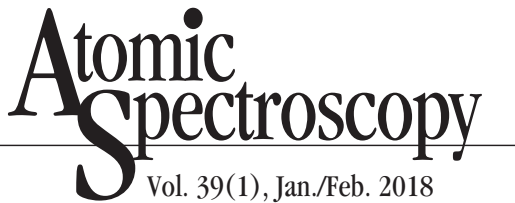

\section{International Geological and Environmental Reference Materials}

A whole range of geological and a few environmental reference materials were used in these investigations, the details of which are listed in Table II. Trace elements in water reference materials NIST1640a, NIST-1643e, and SLRS-5 were used for calibration as well as to check the accuracy of the data.

\section{Sample Dissolution Procedure for Trace Elements and REEs}

Selected rock, mineral, soil, and sediment reference materials (Table II) were dissolved by the wet chemical method following the established protocol (6). A test portion $(0.05 \mathrm{~g})$ of each sample was taken in Savillex ${ }^{\circledR}$ screw top vessels to which $10 \mathrm{~mL}$ of an acid mixture

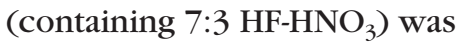
added. Subsequently, $5 \mathrm{~mL}$ of $1 \mathrm{ng} / \mathrm{mL}^{103} \mathrm{Rh}$ solution was added as an internal standard to each vessel. After thorough swirling, they were tightly closed and kept on a hot plate at $\sim 140{ }^{\circ} \mathrm{C}$ for 48 hours. Then the vessels were opened and the contents evaporated at $200{ }^{\circ} \mathrm{C}$ to near dryness with a few drops of $\mathrm{HClO}_{4}$ to ensure complete removal of $\mathrm{HF}$ from the mixture. It was further dissolved by adding $10 \mathrm{~mL}$ of $1: 1 \mathrm{HNO}_{3}$ and the volume was made up to $250 \mathrm{~mL}$ with Milli-Q ${ }^{\circledR}$ de-ionized water, the solution stored in HDPE bottles. A couple of procedural blanks were also prepared with the sample batch by adopting the same protocol described above to negate errors due to reagent and handling. These geological reference samples have well-certified data for all trace elements of interest. In the present investigation, very clear solutions were obtained for all samples.

\section{Sample Preparation for PGE Analysis}

The NiS fire-assay method coupled with tellurium coprecipitation 
has been widely applied for the determination of PGEs and Au in a variety of geological samples (1719). The NiS fire-assay involves fusion of the sample with nickel, sulfur, $\mathrm{Na}_{2} \mathrm{~B}_{4} \mathrm{O}_{7}, \mathrm{Na}_{2} \mathrm{CO}_{3}, \mathrm{CaF}_{2}$, and $\mathrm{SiO}_{2}$ in a clay crucible at a temperature of $\sim 1100{ }^{\circ} \mathrm{C}$. When the sample and flux mixture was heated to a very high temperature, the heavier nickel sulfide phase was produced. The principle of the NiS fire-assay is based on the fact that PGEs and gold are soluble in molten nickel sulfide phase (20). Separation of the NiS button from the slag containing the unwanted elements was based on the large difference in the specific gravity of two phases. A minimum of $10 \mathrm{~g}$ of homogenized rock sample along with appropriate amounts of flux materials were fused in a muffle furnace at $1100^{\circ} \mathrm{C}$ for one hour. Flux contains a mixture of sodium carbonate as basic reagent, while silica and sodium tetraborate as acidic reagent, and nickel, sulfur, and a small amount of flour as a reducing agent. The molten material is swirled to ensure proper mixing and heated for one more hour. The melt was then quickly poured into an iron mold and allowed to cool for one hour. The slag was re-fused with an additional collector to ensure complete recovery of the PGEs. The nickel sulfide buttons were finely ground and dissolved in $400 \mathrm{~mL}$ of concentrated hydrochloric acid on a steam bath for 16 hours. To the boiling solution, a combination of $2 \mathrm{~mL}$ of $1000 \mu \mathrm{g} / \mathrm{mL}$ Te and $5 \mathrm{~mL}$ of $20 \%$ $\mathrm{SnCl}_{2}$ (freshly prepared) were slowly added with constant stirring

TABLE II

List of Geochemical Certified Reference Materials for Rock and Water Used in This Study

\begin{tabular}{|c|c|c|c|}
\hline $\begin{array}{l}\text { Sample } \\
\text { No. }\end{array}$ & $\begin{array}{l}\text { Reference } \\
\text { Material }\end{array}$ & Description & Source \\
\hline 1 & JG-1a & $\begin{array}{l}\text { Sori granodiorite (biotite granodiorite); } 85 \mathrm{Ma} \text {; } \\
\text { Azuma Mura, Gumma Prefecture }\end{array}$ & Geological Survey of Japan (GSJ) \\
\hline 2 & JA-1 & $\begin{array}{l}\text { Augite-Hypersthene-Andesite; Quarternary; } \\
\text { Hakone volcano, old Somma lava; Manazuru-Machi, } \\
\text { Kanagawa Prefecture }\end{array}$ & Geological Survey of Japan $\left(\mathrm{GSJ}^{\mathrm{o}}\right.$ \\
\hline 3 & JB-2 & $\begin{array}{l}\text { Tholeiitic basalt, augite-bronzite basalt; } \\
\text { northern rim of Mihara crater, O-shima, Tokyo }\end{array}$ & Geological Survey of Japan (GSJ) \\
\hline 4 & BHVO-1 & $\begin{array}{l}\text { A basaltic lava from Kilauea caldera, } \\
\text { Kilauea volcano, Hawaii }\end{array}$ & U.S. Geological Survey (USGS) \\
\hline 5 & UB-N & $\begin{array}{l}\text { Serpentine from the col des Bagenelles (Vosges), } \\
\text { France }\end{array}$ & $\begin{array}{l}\text { Association Nationale de la Recherche } \\
\text { Technique (ANRT), Paris, France }\end{array}$ \\
\hline 6 & SY-3 & $\begin{array}{l}\text { Syenite from the Bancroft acea of Eastern } \\
\text { Ontario, Canada }\end{array}$ & CCRMP-CANMET-MMSL, Canada \\
\hline 7 & JGb-2 & $\begin{array}{l}\text { Tsukuba-san leucogabbro, Tsukuba tunnel no.2, } \\
\text { Yasato, Ibaraki }\end{array}$ & Geological Survey of Japan (GSJ) \\
\hline 8 & NOD-P1 & Manganese nodule (from Central Pacific Ocean) & U.S. Geological Survey (USGS) \\
\hline 9 & NOD-A1 & $\begin{array}{l}\text { Manganese nodule (from Blake Plateau } \\
\text { in Atlantic Ocean) }\end{array}$ & U.S. Geological Survey (USGS) \\
\hline 10 & WMG-1 & $\begin{array}{l}\text { Mineralized Gabbro; Wellgreen Complex, } \\
\text { Yukon, Canada }\end{array}$ & CCRMP-CANMET-MMSL, Canada \\
\hline 11 & WMS-1A & $\begin{array}{l}\text { Massive Sulphide Ore; Wellgreen Complex, } \\
\text { Yukon, Canada }\end{array}$ & CCRMP-CANMET-MMSL, Canada \\
\hline 12 & SARM-64 & Chromate Platinum Ore Tails & MINTEK, South Africa \\
\hline 13 & PTC-1A & Cu-Ni Sulphide concentrate powder & CCRMP-CANMET-MMSL, Canada \\
\hline 14 & UMT-1 & $\begin{array}{l}\text { Ultramafic mill tailings from Ni-Cu Giant } \\
\text { Mascot Mines, Hope, British Columbia }\end{array}$ & CCRMP-CANMET-MMSL, Canada \\
\hline 15 & NIST-1640a & Natural water & $\begin{array}{l}\text { National Institute of Standards and } \\
\text { Technology (NIST), USA }\end{array}$ \\
\hline 16 & NIST-1643e & Water solution & $\begin{array}{l}\text { National Institute of Standards and } \\
\text { Technology (NIST), USA }\end{array}$ \\
\hline 17 & SLRS-5 & River water & $\begin{array}{l}\text { National Research Council of Canada, } \\
\text { (NRCC) }\end{array}$ \\
\hline
\end{tabular}


until a black turbid precipitate was obtained. The insoluble sulfides were filtered using Whatman No. 542 filter paper and washed with distilled water. The precipitate was dissolved in hydrochloric acid and $\mathrm{H}_{2} \mathrm{O}_{2}$ for subsequent analysis. More details are provided in reference (5).

\section{Data Acquisition}

Prior to sample analysis, the instrument was purged with a $2 \%$ (v/v) $\mathrm{HNO}_{3}$ wash solution for about an hour. During the analysis, the nebulizer system was washed with $2 \% \mathrm{HNO}_{3}$ and Milli-Q water for 60 seconds each in order to clear any trace of the previous sample. The data were acquired after nebulization of the sample for sufficient time which helps to stabilize the plasma before data acquisition. This would also help to achieve sufficiently low blank levels. Procedural blanks, calibration solutions, sample solutions, and reference sample solutions were sequentially analyzed in that order. Mass calibration was extremely stable over a minimum period of 12 hours. The instrument sensitivity and stability was monitored using the internal standards. Periodic cleaning of the sampler and skimmer cones, torch injector, nebulizer, spray chamber in an ultrasonic bath, and replacement of the sample introduction tubing were carried out meticulously. Blank solutions were run inbetween sample solutions in order to monitor the contamination effects. Since very dilute solutions (50,000 times) were used for analysis, the non-spectroscopic or spectroscopic interferences were expected to be minimum as the matrix between the calibration standard and sample was always the same to a certain extent. Even acid concentrations were also minimum because of the small volume of rock powder used (50 mg). In the present investigation, only solutions of $0.002 \%$ TDS and $<2 \%$ $\mathrm{HNO}_{3}$ were nebulized.

\section{RESULTS AND DISCUSSION}

In order to develop a fast and reliable routine method for the analysis of geological samples for geochemical and environmental studies, a number of certified international geological and environmental reference materials were investigated by HR-ICP-MS. There were other areas such as sample dissolution, resolving matrix, and spectroscopic interferences at different concentrations of major, minor, trace elements, and other components in the matrix (e.g., acid, plasma gas components) where it requires attention during proper calibration. Other possible factors that could affect the performance of HR-ICP-MS were variations in plasma ionization efficiency, possible clogging or corrosion of cone apertures, and temperature and humidity fluctuations in the laboratory environment.

\section{Sample Dissolution, Internal Standards, and Instrument Optimization}

Most methods for the analysis of geological and environmental materials, except water samples, require the sample to be in solution form. Generally, rock samples require mechanical sample preparation, such as drying, grinding, sieving, and homogenizing before a suitable quantity is taken for dissolution. Sample preparation and digestion were the main controlling factors influencing the quality of the analytical results. Since international reference materials were used in the present investigation, sample homogeneity was considered to be good. The pressure decomposition method used in this investigation was very effective and yielded clear solutions in all cases. Very low blank values were obtained for most of the elements investigated. The sample uptake rate, nebulizer gas flow, detector voltage and lens voltages were optimized using

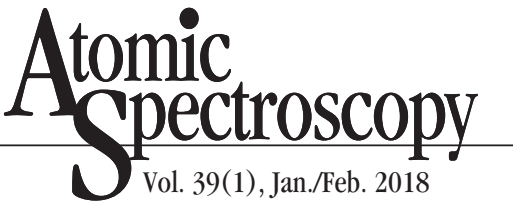

$1 \mathrm{ng} / \mathrm{mL}^{115}$ In solution (Table I). The oxide and doubly charged ion formation levels measured on $\mathrm{CeO}$ and $\mathrm{Ba}^{++}$were found to be $<0.5 \%$ and $<2 \%$, respectively. This was to ensure that the oxide ions and doubly charged ion interferences were not significant. In general, a change in sensitivity of a particular analyte was observed with time which largely depends on physical properties such as atomic mass, ionization potential, concomitant elements, and the temperature of the plasma (largely dependent on the variations in the physical behavior of the analyte in the plasma). While this effect can negatively affect the accuracy of the results, normally it was relatively easy to compensate by using an internal standard such as In or Rh. Several instrumental and sample-induced variations such as electronic drift, physical interferences such as sample nebulization and transport processes in the sample introduction system due to differences in total dissolved solids (TDS), acid concentrations, possible clogging or corrosion of cone apertures, and also other factors like temperature and humidity fluctuations in the laboratory environment, affect the accuracy of the determination (21). Nebulization and transport processes can be affected if a matrix component causes a change in surface tension or viscosity. In addition, massdependent matrix effects such as space-charge effects control ion transmission efficiencies because of the relatively high concentrations (22). In order to compensate for most of these effects, ${ }^{103} \mathrm{Rh}$ was chosen as the internal standard since the concentration of $\mathrm{Rh}$ was found to be at negligible levels in the samples investigated. Moreover, ${ }^{103} \mathrm{Rh}$ also lies in the central part of the mass range measured from low to high mass. Several studies have revealed that a single internal standard is sufficient for the accurate measurement of trace and ultra- 
trace elements in geological materials $(4,23)$.

\section{Resolving Power and Limits of Detection}

A resolution of 300 (300R) was used for the present study as it was observed that when the resolution is changed from one value to another through variable slits, normally the original resolution setting is not achieved when the system returns back to normal in (or after) a single run. Either the analytical session needs to be separated into two or more parts or all the trace elements in different sessions should be analyzed and aggregated to make a best fit. Moreover, the time involved in shifting of the resolution decreases the sample throughput when executing geochemical and environmental analysis programs, in general, mandate quick data acquisitions. According to some authors, the background signal can be suppressed effectively at low mass resolution $(\mathrm{R} \sim 300)$ $(24,25)$. Extensive studies were made on various significant polyatomic and doubly charged interferences observed for trace elements determined by ICP-MS in geological samples. The optimal modes of mass spectrum resolution can be chosen depending on the chemical composition of the test sample, concentration of the analyte element, presence of concomitant and interfering elements and their concentration levels. Hence, a uniform resolution of 300 was maintained during the multielement analytical work for all of the trace elements including REEs and PGEs. It was observed that 300R was sufficient to achieve the required accuracy and precision with an uncertainty less than 2\% RSD for those in $\mu \mathrm{g} / \mathrm{mL}$ levels and less than $5 \% \mathrm{RSD}$ for those in $\mathrm{ng} / \mathrm{mL}$ and $\mathrm{pg} / \mathrm{mL}$ levels in the original geological samples. The detection limits (DLs) were calculated as $3 \sigma(\sigma=$ standard deviation) of 10 blank sam- ples measured for various trace elements including REEs and PGEs, and are listed in Table III. Nevertheless, it should be emphasized that the DLs even at low resolution exceeded at least an order of magnitude from those obtained in quadrupole-based systems (4). DLs for several elements determined in this investigation are in the range of femto-gram and sub-femtogram levels. The sample solutions for trace elements including REEs were diluted several times $(\sim 50,000$ times) maintaining the TDS levels to approximately $0.002 \%$. Use of relatively smaller quantities of high purity acids and other reagents during sample dissolution in a closed environment led to extremely low blank values. This has resulted in extremely low detection limits for several elements including REEs and PGEs (Table III).

\section{Calibration Strategies}

Matrix effects are common in geological matrices and their potential spectral interferences are well understood. Several methods are available to overcome their effect namely, dilution of the sample, use of internal standards, matrix matching of the samples and calibration standards, etc. A specific resolution setting (300R) was chosen for the groups of analytes in this HR-ICPMS work. Moreover, to the extent possible, the isotopes chosen were either completely interference-free or have minimum interference effect, except for the monoisotopic elements. However, 300R was maintained throughout the multi-element analytical work for all trace elements including REEs, ${ }^{103} \mathrm{Rh}$ was used as an internal standard at the $2-\mathrm{ng} / \mathrm{mL}$ level in the final solution. Blank subtraction was carried out using a procedural blank on all measurements selectively. Calibration graphs (Figure 1) were prepared using 1, 10, and 100 $\mathrm{ng} / \mathrm{mL}$ standards prepared from a stock solution of $50 \mu \mathrm{g} / \mathrm{mL}$ (LGC
Standards, Germany). The geochemical reference materials representing acidic, basic, alkaline, and intermediate rocks (JG-1a, JGb-2, JA-1, SY-3, NOD-A1, NOD-P1, WMG-1, WMS-1A, SARM-64, PTC1A, UMT-1, NIST1640a, NIST1643e, SLRS-5, NASS-5, and CASS-4) were used to check the accuracy and precision of the analytical work.

\section{REEs and Trace Elements}

The trace and REE data obtained from analyzing acidic (JG-1A, JA-1), basic (JB-2, BHVO-1), and ultrabasic (UB-N) reference materials by HRICP-MS are listed in Table IV and are compared with their certified values wherever available. The comparative data by both methods (ICP-QMS and HR-ICPMS) in comparison with certified values are presented in Table $\mathrm{V}$. The chondrite-normalized REE patterns of the rock reference samples representing mafic (JGb-2) and ferromanganese (NOD-A1, NOD-P1) composition using data from both ICP-QMS and HR-ICPMS are shown in Figure 2. REE abundances in rocks and their chondrite-normalized patterns provide information on features such as high- or lowpressure formation (grade) and thus enable to understand the fractionation pattern of different geological matrices. In addition, all REEs as a whole exhibit similar physical and chemical properties, except Eu and Ce because of their variable oxidation states. Ce may be oxidized to $\mathrm{Ce}^{4+}$, Eu may be reduced to $\mathrm{Eu}^{2+}$ depending on the environment (oxidizing or reducing), while the rest of the REEs are mostly stable in the trivalent state. The anomalous behavior of cerium and europium, together with the coherent behavior of the rest of the series, is used extensively as a tool to study geochemical processes within the Earth's mantle and crust as well as in natural waters. A pronounced dip in the REE pattern for Eu is observed in the presence of a min- 


\section{Atomic Apectroscopy \\ Vol. 39(1), Jan./Feb. 2018}

TABLE III

Comparative Detection Limits of HR-ICP-MS (pg/mL) Operated at Resolution 300R With Those of ICP-QMS $(\mathrm{ng} / \mathrm{mL})$

Isotopes Analyzed, Detection Limits (DLs), and Resolutions

(DLs Calculated as Three Times the Standard Deviation of 10 Blanks Measured)

\begin{tabular}{|c|c|c|c|c|c|}
\hline Element & $\begin{array}{c}\text { ICP-QMS } \\
\text { DL (ng/mL) }\end{array}$ & $\begin{array}{c}\text { HR-ICP-MS } \\
\text { DL (pg/mL) }\end{array}$ & Element & $\begin{array}{c}\text { ICP-QMS } \\
\text { DL (ng/mL) }\end{array}$ & $\begin{array}{l}\text { HR-ICP-MS } \\
\text { DL (pg/mL) }\end{array}$ \\
\hline${ }^{7} \mathrm{Li}$ & 12.25 & 1.031 & ${ }^{121} \mathrm{Sb}$ & 6.13 & 0.021 \\
\hline${ }^{9} \mathrm{Be}$ & 14.71 & 0.0009 & ${ }^{124} \mathrm{Te}$ & 4.90 & 0.049 \\
\hline${ }^{11} \mathrm{~B}$ & 13.12 & 1.055 & ${ }^{133} \mathrm{Cs}$ & 1.96 & 0.110 \\
\hline${ }^{23} \mathrm{Na}$ & 61.27 & 35.04 & ${ }^{137} \mathrm{Ba}$ & 12.25 & 2.233 \\
\hline${ }^{24} \mathrm{Mg}$ & 24.51 & 3.092 & ${ }^{139} \mathrm{La}$ & 12.74 & 0.128 \\
\hline${ }^{27} \mathrm{Al}$ & 12.47 & 0.368 & ${ }^{140} \mathrm{Ce}$ & 0.61 & 0.188 \\
\hline${ }^{44} \mathrm{Ca}$ & 490.17 & 46.99 & ${ }^{141} \mathrm{Pr}$ & 0.72 & 0.056 \\
\hline${ }^{45} \mathrm{Sc}$ & 11.03 & 0.232 & ${ }^{146} \mathrm{Nd}$ & 2.45 & 0.243 \\
\hline${ }^{51} \mathrm{~V}$ & 12.69 & 0.099 & ${ }^{147} \mathrm{Sm}$ & 0.98 & 0.162 \\
\hline${ }^{53} \mathrm{Cr}$ & 6.13 & 0.099 & ${ }^{153} \mathrm{Eu}$ & 0.37 & 0.022 \\
\hline${ }^{55} \mathrm{Mn}$ & 6.74 & 0.091 & ${ }^{157} \mathrm{Gd}$ & 0.98 & 0.156 \\
\hline${ }^{57} \mathrm{Fe}$ & 612.72 & 7.650 & ${ }^{159} \mathrm{~Tb}$ & 0.07 & 0.015 \\
\hline${ }^{59} \mathrm{Co}$ & 12.25 & 0.140 & ${ }^{163}$ Dy & 1.41 & 0.106 \\
\hline${ }^{60} \mathrm{Ni}$ & 12.37 & 0.002 & ${ }^{165} \mathrm{Ho}$ & 0.07 & 0.023 \\
\hline${ }^{63} \mathrm{Cu}$ & 6.13 & 0.012 & ${ }^{166} \mathrm{Er}$ & 0.11 & 0.076 \\
\hline${ }^{66} \mathrm{Zn}$ & 49.02 & 0.163 & ${ }^{169} \mathrm{Tm}$ & 0.37 & 0.019 \\
\hline${ }^{71} \mathrm{Ga}$ & 2.45 & 0.560 & ${ }^{172} \mathrm{Yb}$ & 0.37 & 0.080 \\
\hline${ }^{75}$ As & 5.56 & 1.241 & ${ }^{175} \mathrm{Lu}$ & 0.02 & 0.026 \\
\hline${ }^{77} \mathrm{Se}$ & 55.56 & 2.674 & ${ }^{178} \mathrm{Hf}$ & 1.23 & 0.135 \\
\hline${ }^{85} \mathrm{Rb}$ & 6.13 & 0.398 & ${ }^{181} \mathrm{Ta}$ & 0.37 & 0.003 \\
\hline${ }^{88} \mathrm{Sr}$ & 1.23 & 0.183 & ${ }^{182} \mathrm{~W}$ & 3.68 & 0.062 \\
\hline${ }^{89} \mathrm{Y}$ & 3.68 & 0.295 & ${ }^{185} \mathrm{Re}$ & 2.45 & 0.011 \\
\hline${ }^{90} \mathrm{Zr}$ & 8.58 & 0.664 & ${ }^{189} \mathrm{Os}$ & 12.25 & 0.067 \\
\hline${ }^{93} \mathrm{Nb}$ & 2.14 & 0.136 & ${ }^{193} \mathrm{Ir}$ & 6.13 & 0.019 \\
\hline${ }^{95} \mathrm{Mo}$ & 98.03 & 0.135 & ${ }^{195} \mathrm{Pt}$ & 5.95 & 0.049 \\
\hline${ }^{101} \mathrm{Ru}$ & 12.91 & 0.030 & ${ }^{197} \mathrm{Au}$ & 7.19 & 0.053 \\
\hline${ }^{103} \mathrm{Rh}$ & 12.25 & 0.023 & ${ }^{200} \mathrm{Hg}$ & 10.22 & 0.547 \\
\hline${ }^{105} \mathrm{Pd}$ & 12.11 & 0.057 & ${ }^{205} \mathrm{Tl}$ & 8.46 & 0.003 \\
\hline${ }^{107} \mathrm{Ag}$ & 6.13 & 0.507 & ${ }^{208} \mathrm{~Pb}$ & 1.47 & 0.013 \\
\hline${ }^{111} \mathrm{Cd}$ & 6.43 & 0.040 & ${ }^{209} \mathrm{Bi}$ & 0.61 & 0.008 \\
\hline${ }^{115} \mathrm{In}$ & 5.57 & 0.010 & ${ }^{232} \mathrm{Th}$ & 0.12 & 0.013 \\
\hline${ }^{118} \mathrm{Sn}$ & 3.68 & 0.054 & ${ }^{238} \mathrm{U}$ & 0.74 & 0.031 \\
\hline
\end{tabular}




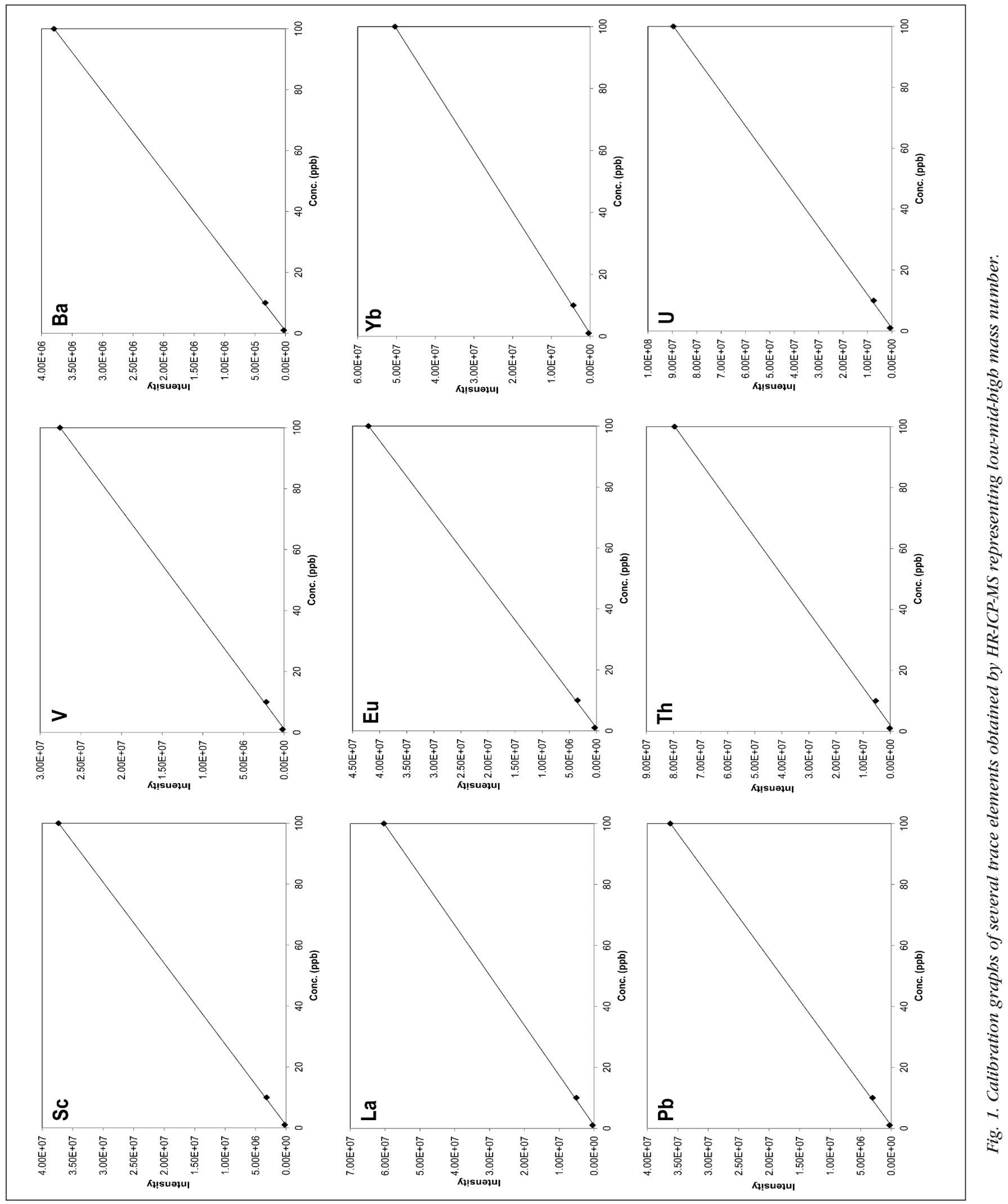




\section{Atomic Apectroscopy \\ Vol. 39(1), Jan./Feb. 2018}
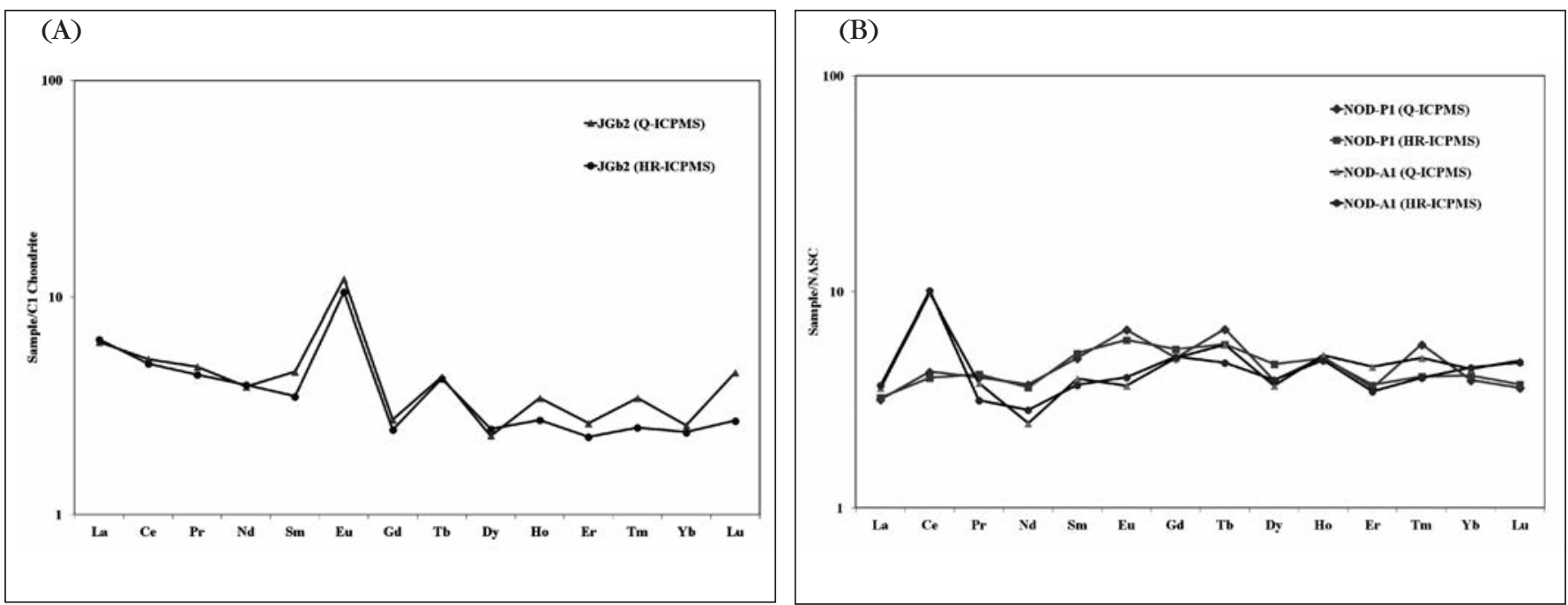

Fig. 2. Chondrite-normalized REE patterns of (A) JGb-2, (B) NOD-P1 and NOD-A1 geochemical reference samples from the data obtained by ICP-QMS and HR-ICP-MS.

eral called 'plagioclase' due to the $\mathrm{Eu}^{2+}$ substitution for $\mathrm{Ca}^{2+}$. The anomaly may be either positive or negative (positive in Figure 2A) depending on whether plagioclase was removed or accumulated during the rock's formation $(2,26)$.

The Ce anomalies are common in the marine environment (27). For example, the preferential incorporation of $\mathrm{Ce}$ in manganese nodules is generally considered to be due to the oxidation of $\mathrm{Ce}^{3+}$ to $\mathrm{Ce}^{4+}$ under oxidizing conditions, with consequent reduction of its ionic radius. This results in the precipitation of cerium hydroxide and phosphates in manganese nodules. As a result, Ce-positive anomaly is seen in the REE patterns (Figure 2B). This also explains the dramatic depletion of Ce in seawater compared to other REEs. This property is used to understand paleo-redox conditions in ancient oceans (28). Smooth chondrite-normalized curves were obtained for the rock reference samples studied here, and it was observed that the plots made from HR-ICP-MS data are much better resolved than those from ICP-QMS. The uncertainty value obtained from HR-ICP-MS is far superior to that of the ICP-QMS (Table V) due to its capability to resolve the $\mathrm{m} / \mathrm{z}$ and reduce the interference. This demonstrates that the data obtained in this study possessed the accuracy and precision required for geochemical studies. Thus, the REE chondrite-normalized curves also provide the additional assessment of the accuracy of the analysis.

\section{Platinum Group Elements}

PGE exploration studies usually involve various stages, such as reconnaissance study, detailed follow-up, anomaly delineation and target definition, resource estimation, and reserve calculation. In all of these stages, documenting PGE distributions in a particular area and identifying anomalous concentrations were essential to locate and develop PGE mine sites and to understand the dispersal of these metals in geological systems.

Usually a very large number of rock and ore samples are collected in such exploration programs. Hence, the methods developed must be simple, easy, cost-effective, and rapid. Precious metals were generally found to be heterogeneously distributed within an ore body and tend to be agglomerated in discrete particles or mineral phases. Our earlier studies $(5,19)$ have shown that sample masses of typically $10 \mathrm{~g}$ or above taken for analysis have yielded reproducible results. Hence, a minimum of $10 \mathrm{~g}$ of sample was used in each case for the determination of PGEs in these studies. Although $\mathrm{Pb}$ fire-assay is the best method for gold, the NiS fire-assay method has an advantage of collecting all PGEs in addition to $\mathrm{Au}$ (29). For the determination of PGEs and $\mathrm{Au},{ }^{205} \mathrm{Tl}$ at $20 \mathrm{ng} / \mathrm{mL}$ was used as an internal standard which was added to the sample during the course of the sample preparation along with a Te solution to co-precipitate as tellurides (gold telluride, $\mathrm{TePtCl}_{2}, \mathrm{TePdCl}_{2}$, etc.). PGE and Au data are presented in Table VI. Matrix interferences were minimized by utilizing matrix matching reference material solutions for calibration. Major spectroscopic interferences were resolved by using a resolution setting of 300R. Linear calibration curves were obtained and very close agreement $(<2 \%$ RSD) was found between the certified and obtained values. With HRICP-MS, the reagent blank becomes the limiting factor for accurate determination of these elements. 


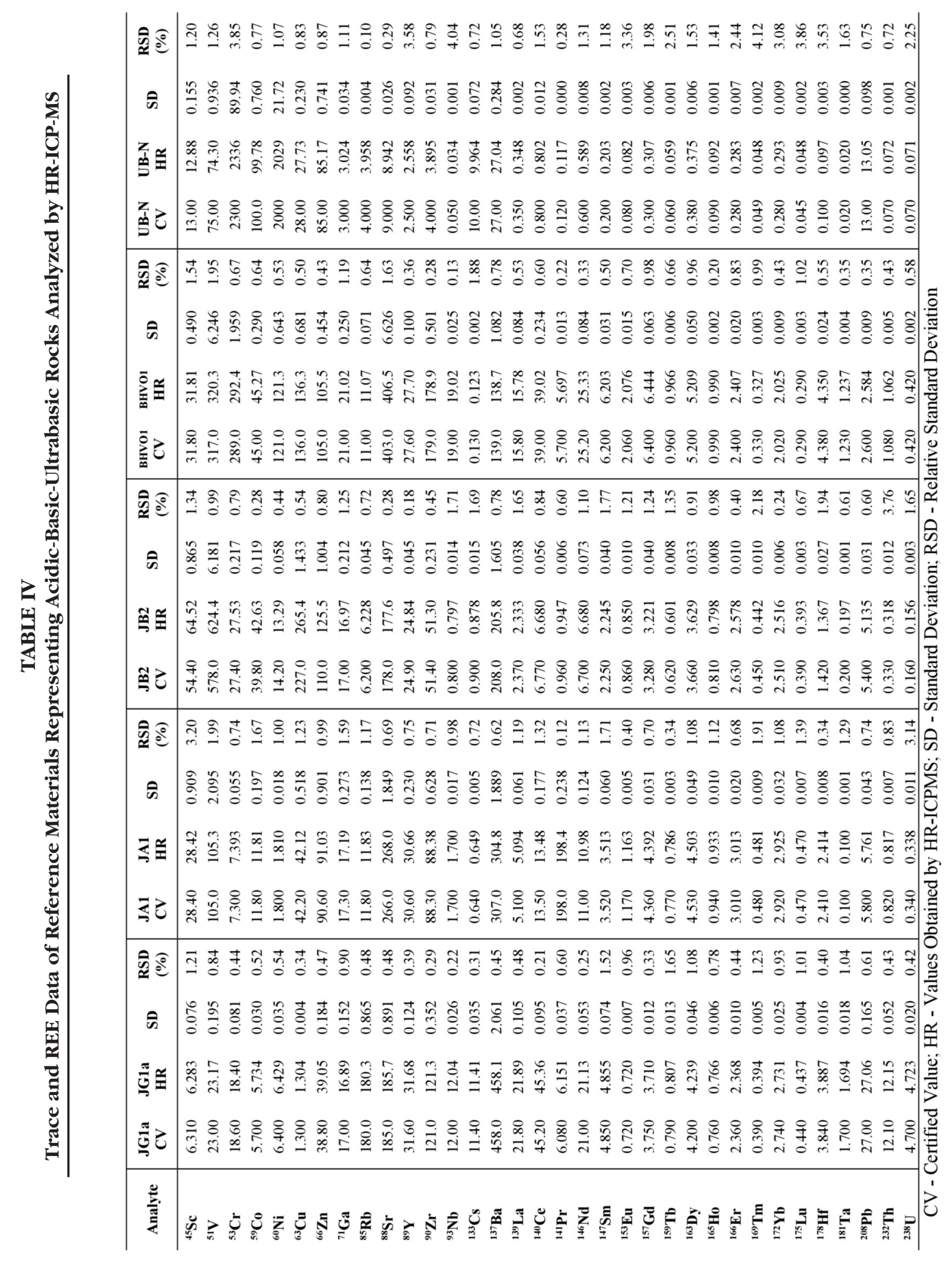




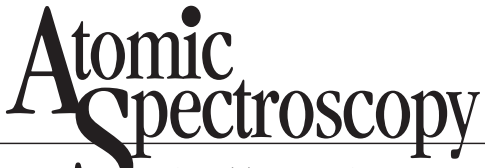 \\ $\bigcup$ Vol. 39(1), Jan./Feb. 2018}

TABLE V

Comparative Data of SY-3, JGb-2 Representing Mafic-Alkaline Rocks and NOD-P1, NOD-A1 Representing Marine Reference Material Analyzed by ICP-QMS and HR-ICPMS

\begin{tabular}{|c|c|c|c|c|c|c|c|c|c|c|c|c|}
\hline \multirow{2}{*}{ Analyte } & \multicolumn{3}{|c|}{ SY3 } & \multicolumn{3}{|c|}{ JGb 2} & \multicolumn{3}{|c|}{ NOD-P1 } & \multicolumn{3}{|c|}{ NOD-A1 } \\
\hline & $\begin{array}{l}\text { Certified } \\
\text { Value }\end{array}$ & $\underset{\text { ICPMS }}{\text { Q- }}$ & $\underset{\text { ICPMS }}{\text { HCP- }}$ & $\begin{array}{c}\text { Certified } \\
\text { Value }\end{array}$ & ICPMS & $\underset{\text { ICPMS }}{\text { HR- }}$ & $\begin{array}{c}\text { Certified } \\
\text { Value }\end{array}$ & ICPMS & $\underset{\text { ICPMS }}{\text { HR- }}$ & $\begin{array}{c}\text { Certified } \\
\text { Value }\end{array}$ & ICPMS & $\underset{\text { ICPMS }}{\text { HR- }}$ \\
\hline${ }^{139} \mathrm{La}$ & 1340 & $\begin{array}{c}1322 \\
\pm 62.13\end{array}$ & $\begin{array}{c}1337 \\
\pm 25.12\end{array}$ & 1.500 & $\begin{array}{l}1.472 \\
\pm 0.11\end{array}$ & $\begin{array}{r}1.514 \\
\pm 0.041\end{array}$ & 104 & $\begin{array}{c}102.062 \\
\pm 7.16\end{array}$ & $\begin{array}{c}103.975 \\
\pm 2.12\end{array}$ & 118 & $\begin{array}{c}115.051 \\
\pm 5.81\end{array}$ & $\begin{array}{c}118.427 \\
\pm 1.38\end{array}$ \\
\hline${ }^{140} \mathrm{Ce}$ & 2230 & $\begin{array}{c}2120 \\
\pm 99.04\end{array}$ & $\begin{array}{c}2234 \\
\pm 43.77\end{array}$ & 3.000 & $\begin{array}{l}3.150 \\
\pm 0.24\end{array}$ & $\begin{array}{c}3.005 \\
\pm 0.088\end{array}$ & 294 & $\begin{array}{l}312.959 \\
\pm 15,78\end{array}$ & $\begin{array}{c}293.057 \\
\pm 4.86\end{array}$ & 732 & $\begin{array}{l}720.834 \\
\pm 41.01\end{array}$ & $\begin{array}{l}738.571 \\
\pm 13.78\end{array}$ \\
\hline${ }^{1+1} \mathrm{Pr}$ & 223 & $\begin{array}{c}232.7 \\
\pm 15.29\end{array}$ & $\begin{array}{l}226.6 \\
\pm 5.23\end{array}$ & 0,390 & $\begin{array}{l}0.429 \\
\pm 0.03\end{array}$ & $\begin{array}{c}0.394 \\
\pm 0.015\end{array}$ & 33 & $\begin{array}{l}31.893 \\
\pm 2.14\end{array}$ & $\begin{array}{l}32.939 \\
\pm 0.89\end{array}$ & 25 & $\begin{array}{l}30.010 \\
\pm 2.44\end{array}$ & $\begin{array}{l}24.901 \\
\pm 0.66\end{array}$ \\
\hline${ }^{146} \mathrm{Nd}$ & 670 & $\begin{array}{c}636.1 \\
\pm 35.17\end{array}$ & $\begin{array}{l}676.3 \\
\pm 19.78\end{array}$ & 1.800 & $\begin{array}{l}1.764 \\
\pm 0.13\end{array}$ & $\begin{array}{l}1.796 \\
\pm 0.033\end{array}$ & 120 & $\begin{array}{c}123.200 \\
\pm 6.39\end{array}$ & $\begin{array}{c}119.443 \\
\pm 1.39\end{array}$ & 94 & $\begin{array}{l}81.647 \\
\pm 4.28\end{array}$ & $\begin{array}{l}93.857 \\
\pm 1.79\end{array}$ \\
\hline${ }^{147} \mathrm{Sm}$ & 109 & $\begin{array}{r}113.9 \\
\pm 6.84\end{array}$ & $\begin{array}{l}110.5 \\
\pm 2.32\end{array}$ & 0,510 & $\begin{array}{l}0.672 \\
\pm 0.04\end{array}$ & $\begin{array}{c}0.516 \\
\pm 0.014\end{array}$ & 30 & $\begin{array}{l}28.272 \\
\pm 1.47\end{array}$ & $\begin{array}{l}29.737 \\
\pm 0.88\end{array}$ & 21.1 & $\begin{array}{l}22.659 \\
\pm 1.32\end{array}$ & $\begin{array}{l}21.174 \\
\pm 0.54\end{array}$ \\
\hline${ }^{153} \mathbf{E u}$ & 17 & $\begin{array}{r}16.36 \\
\pm 1.14\end{array}$ & $\begin{array}{l}17.32 \\
\pm 0.59\end{array}$ & 0.590 & $\begin{array}{l}0.681 \\
\pm 0.04\end{array}$ & $\begin{array}{l}0.592 \\
\pm 0.015\end{array}$ & 7.5 & $\begin{array}{l}8.324 \\
\pm 0.81\end{array}$ & $\begin{array}{l}7.472 \\
\pm 0.21\end{array}$ & 4.96 & $\begin{array}{l}4.576 \\
\pm 0.38\end{array}$ & $\begin{array}{r}5.001 \\
\pm 0.15\end{array}$ \\
\hline${ }^{157} \mathrm{Gd}$ & 105 & $\begin{array}{r}109.7 \\
\pm 5.59\end{array}$ & $\begin{array}{r}106.5 \\
\pm 2.21\end{array}$ & 0.480 & $\begin{array}{l}0.541 \\
\pm 0.03\end{array}$ & $\begin{array}{c}0.486 \\
\pm 0.005\end{array}$ & 28.2 & $\begin{array}{l}25.792 \\
\pm 1.52\end{array}$ & $\begin{array}{l}28.328 \\
\pm 0.75\end{array}$ & 26.1 & $\begin{array}{c}25.770 \\
\pm 1.71\end{array}$ & $\begin{array}{l}26.127 \\
\pm 0.61\end{array}$ \\
\hline${ }^{159} \mathrm{~Tb}$ & 18 & $\begin{array}{r}17.09 \\
\pm 1.42\end{array}$ & $\begin{array}{l}18.17 \\
\pm 0.63\end{array}$ & 0.150 & $\begin{array}{l}0.156 \\
\pm 0.01\end{array}$ & $\begin{array}{c}0.153 \\
\pm 0.012\end{array}$ & 4.9 & $\begin{array}{r}5.746 \\
\pm 0.31\end{array}$ & $\begin{array}{l}4.880 \\
\pm 0.15\end{array}$ & 4 & $\begin{array}{l}4.854 \\
\pm 0.31\end{array}$ & $\begin{array}{l}4.008 \\
\pm 0.11\end{array}$ \\
\hline${ }^{163} \mathbf{D y}$ & 118 & $\begin{array}{r}123.5 \\
\pm 5.25\end{array}$ & $\begin{array}{r}119.4 \\
\pm 2.58\end{array}$ & 0.600 & $\begin{array}{l}0.562 \\
\pm 0.03\end{array}$ & $\begin{array}{l}0.604 \\
\pm 0.017\end{array}$ & 27 & $\begin{array}{l}22.623 \\
\pm 1.11\end{array}$ & $\begin{array}{l}26.907 \\
\pm 0.72\end{array}$ & 22.8 & $\begin{array}{l}21.341 \\
\pm 1.29\end{array}$ & $\begin{array}{l}22,709 \\
\pm 0.57\end{array}$ \\
\hline${ }^{165} \mathrm{Ho}$ & 29.5 & $\begin{array}{l}28.14 \\
\pm 2.30\end{array}$ & $\begin{array}{l}29.93 \\
\pm 1.14\end{array}$ & 0.150 & $\begin{array}{l}0.194 \\
\pm 0.02\end{array}$ & $\begin{array}{l}0.153 \\
\pm 0.005\end{array}$ & 5.13 & $\begin{array}{l}5.210 \\
\pm 0.31\end{array}$ & $\begin{array}{l}5.144 \\
\pm 0.11\end{array}$ & 5 & $\begin{array}{l}5.314 \\
\pm 0.38\end{array}$ & $\begin{array}{l}5.031 \\
\pm 0.14\end{array}$ \\
\hline${ }^{166} \mathrm{Er}$ & 68 & $\begin{array}{l}71.20 \\
\pm 5.20\end{array}$ & $\begin{array}{l}68.87 \\
\pm 2.01\end{array}$ & 0.360 & $\begin{array}{l}0.420 \\
\pm 0,02\end{array}$ & $\begin{array}{c}0.364 \\
\pm 0.010\end{array}$ & 12.5 & $\begin{array}{l}12.269 \\
\pm 0.88\end{array}$ & $\begin{array}{l}12.639 \\
\pm 0.27\end{array}$ & 11.7 & $\begin{array}{l}15.346 \\
\pm 0.85\end{array}$ & $\begin{array}{l}11.806 \\
\pm 0.33\end{array}$ \\
\hline${ }^{169} \mathrm{Tm}$ & 11 & $\begin{array}{l}10.09 \\
\pm 0.95\end{array}$ & $\begin{array}{l}11.78 \\
\pm 0.25\end{array}$ & 0.059 & $\begin{array}{l}0.083 \\
\pm 0.01\end{array}$ & $\begin{array}{c}0.061 \\
\pm 0.002\end{array}$ & 2.03 & $\begin{array}{r}2.865 \\
\pm 0.23\end{array}$ & $\begin{array}{l}2.038 \\
\pm 0.07\end{array}$ & 2 & $\begin{array}{l}2.480 \\
\pm 0.22\end{array}$ & $\begin{array}{l}2.006 \\
\pm 0.07\end{array}$ \\
\hline${ }^{172} \mathbf{Y b}$ & 62 & $\begin{array}{l}64.49 \\
\pm 4.16\end{array}$ & $\begin{array}{l}63.22 \\
\pm 1.05\end{array}$ & 0.390 & $\begin{array}{l}0.420 \\
\pm 0.03\end{array}$ & $\begin{array}{c}0.392 \\
\pm 0.011\end{array}$ & 13 & $\begin{array}{l}12.152 \\
\pm 0.93\end{array}$ & $\begin{array}{l}12.759 \\
\pm 0.37\end{array}$ & 13.8 & $\begin{array}{l}13.689 \\
\pm 0.86\end{array}$ & $\begin{array}{l}13.895 \\
\pm 0.31\end{array}$ \\
\hline${ }^{175} \mathbf{L u}$ & 7.9 & $\begin{array}{r}7.614 \\
\pm 0.49\end{array}$ & $\begin{array}{l}8.088 \\
\pm 0.33\end{array}$ & 0.062 & $\begin{array}{c}0.109 \\
\pm 0.01\end{array}$ & $\begin{array}{c}0.065 \\
\pm 0.005\end{array}$ & 1.8 & $\begin{array}{r}1.733 \\
\pm 0.13\end{array}$ & $\begin{array}{r}1.796 \\
\pm 0.06\end{array}$ & 2.24 & $\begin{array}{l}2.311 \\
\pm 0.17\end{array}$ & $\begin{array}{l}2.273 \\
\pm 0.08\end{array}$ \\
\hline
\end{tabular}

TABLE VI

Analytical Data of PGE and Au (in ng/g) by HR-ICP-MS in Reference Materials (CV = Certified Value, NGRI = National Geophysical Research Institute $)$

\begin{tabular}{|c|c|c|c|c|c|c|}
\hline $\begin{array}{l}\text { Analyte } \\
\text { Mass No. }\end{array}$ & $\begin{array}{r}\mathrm{Ru} \\
101\end{array}$ & $\begin{array}{c}\mathrm{Rh} \\
103 \\
\end{array}$ & $\begin{array}{c}\mathrm{Pd} \\
105\end{array}$ & $\begin{array}{c}\text { Ir } \\
193\end{array}$ & $\begin{array}{c}\mathrm{Pt} \\
195\end{array}$ & $\begin{array}{c}\mathrm{Au} \\
197\end{array}$ \\
\hline WMG1 CV & 35.00 & 26.00 & 382.00 & 46.00 & 731.00 & 110.00 \\
\hline WMG1 (NGRI) & 35.38 & 26.21 & 393.24 & 46.83 & 740.61 & 107.91 \\
\hline$\%$ RSD & 1.64 & 1.92 & 2.55 & 1.30 & 1.30 & 3.42 \\
\hline WMS-1A CV & NA & 220.00 & 1450.00 & NA & 1910.00 & NA \\
\hline WMS1A (NGRI) & 144.48 & 224.83 & 1416.69 & 341.27 & 2008.02 & 165.25 \\
\hline$\%$ RSD & 1.45 & 1.40 & 1.35 & 1.74 & 1.56 & 2.03 \\
\hline SARM-64 CV & 240.00 & 80.00 & 210.00 & 52.00 & 475.00 & 18.00 \\
\hline SARM64 (NGRI) & 208.95 & 72.10 & 205.14 & 59.65 & 469.98 & 21.30 \\
\hline$\% \mathrm{RSD}$ & 1.29 & 1.50 & 2.53 & 1.36 & 1.22 & 5.04 \\
\hline PTC-1A CV & NA & 330.00 & 4480.00 & NA & 2720.00 & NA \\
\hline PTC-1A (NGRI) & 157.77 & 320.82 & 4365.15 & 100.71 & 2637.44 & 1037.7 \\
\hline$\% \mathrm{RSD}$ & 3.21 & 3.85 & 3.43 & 1.90 & 1.56 & 3.02 \\
\hline UMT-1 CV & 10.90 & 9.50 & 106.00 & 8.80 & 179.00 & NA \\
\hline UMT-1 (NGRI) & 12.91 & 11.57 & 102.64 & 8.72 & 181.49 & 84.24 \\
\hline$\%$ RSD & 1.89 & 2.48 & 1.24 & 1.24 & 2.11 & 12.66 \\
\hline
\end{tabular}




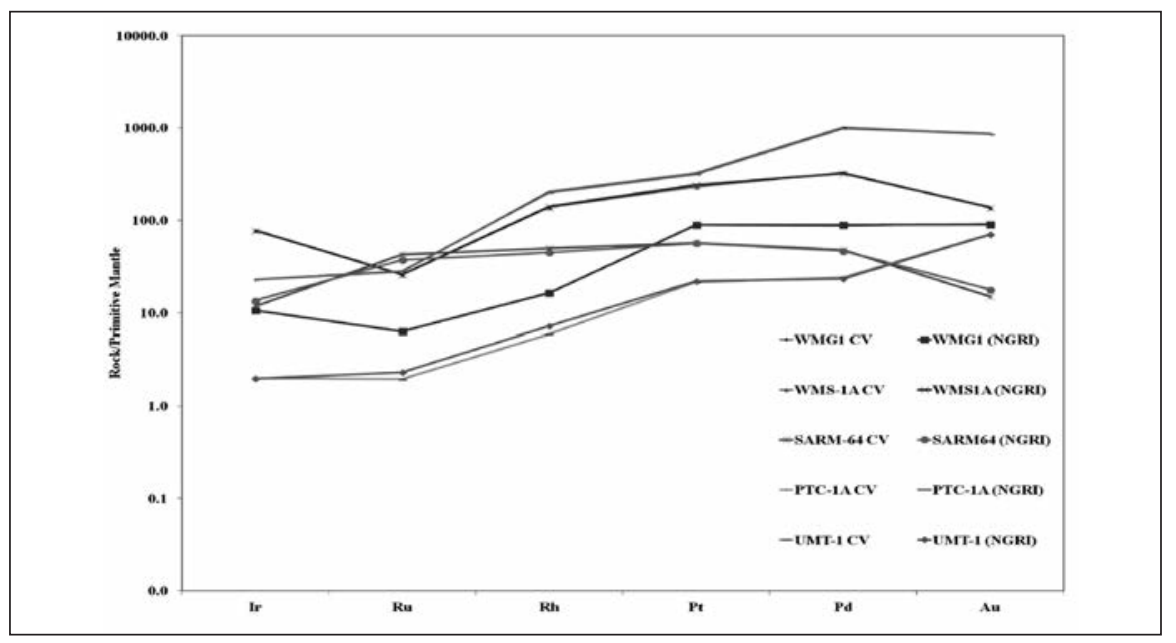

Fig. 3. Chondrite-normalized PGE patterns of different geochemical reference samples from the data obtained by HR-ICP-MS.

Hence, the quality of the flux materials, especially that of nickel powder, had to be extremely pure (5). Use of high-purity nickel powder (99.999\%, -100 mesh) has yielded extremely low blank values. In addition, the laboratory environment has to be extremely clean (class 100 or 1000). In addition to the performance characteristics of HR-ICP-MS, these factors also contribute towards obtaining very accurate PGE data. Just like chondrite-normalized REE curves, primitive mantle-normalized PGE and Au distribution patterns (Figure 3) also provide information on the redistribution of elements within the deposits after emplacement of the sulfide liquid by processes such as fractional crystallization, immiscible sulfide segregation, and diffusion of elements, in response to thermal gradient and hydrothermal activity (30-32).

\section{Analysis of Water}

Commonly, techniques such as inductively coupled plasma optical emission spectrometry (ICP-OES) and ICP-QMS were the techniques of choice for multi-element analyses of water samples $(33,34)$. Recently yet another multi-element analytical technique known as microwave plasma atomic emission spectrometry (MP-AES) made its own mark on water analysis $(34,35)$. The highly resolved and rapid acquisition of data for many elements by HR-ICPMS greatly facilitated groundwater monitoring of several toxic elements and remediation efforts (7). For most elements, detection limits obtained in this study were considerably lower than with the methods based on ICP-QMS (Table III). ${ }^{129} \mathrm{Xe}$ was successfully used as an internal standard in the case of ICP-QMS (28). In general, internal standards are added externally, there exists the possibility of contamination and considerable errors in the data, particularly when the analytes are present at very low concentrations. In view of this, the use of two isotopes of xenon $\left({ }^{129} \mathrm{Xe}\right.$ and $\left.{ }^{132} \mathrm{Xe}\right)$ as internal standards, which are already present as an impurity in the plasma gas (argon) itself, has been attempted. This was of definite advantage since there was no need for external additions and thus minimizes the possibility of external contamination. The concentration of xenon (as an impurity) in any given argon cylinder was found to be always constant throughout the use of the cylinder. Both ${ }^{129} \mathrm{Xe}$ and ${ }^{132} \mathrm{Xe}$ have been used in all of these investigations, since they have about $26.4 \%$ and $26.9 \%$ natural abundance, respectively, and no isobaric overlaps. The trace element data obtained in NIST (National Institute of Standards and Technology, USA) and other reference samples by HRICP-MS are presented in Table VII. It can be seen that the values obtained in this study are very close to the certified values in each case. These results suggest that in addition to the environmental monitoring and remediation efforts, this method can also be effectively utilized for hydrogeo-chemical studies to supplement mineral exploration efforts $(12,36,37)$.

\section{Sensitivity Drift}

One way to check the drift of sensitivity and accuracy of the analysis over time was the repeated analysis of a certified water reference material between the samples at regular intervals. For most elements (Tables IV, V, VI, and VII) for which the concentrations were reported, excellent agreement between experimentally established and certified values were obtained. Precisions better than $2 \%$ RSD with comparable accuracies were found.

\section{CONCLUSION}

This study highlights some of the critical applications of HR-ICP-MS in earth and environmental sciences. Despite continuous progress in the field of quadrupole-based ICP-MS instrumentation, HR-ICP-MS instruments offer the best detection limits, particularly when operated at reasonably low resolution. This is mostly due to the very high analytical signals across the mass range offered by the instrument, and very low blanks which are controlled by several factors such as the laboratory environment and purity of the reagents utilized. Precise data were obtained for REEs and several other trace elements in a variety of 


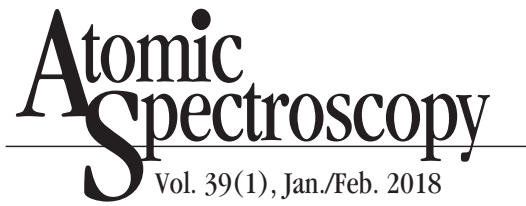

TABLE VII

Major, Minor, and Trace Elements of Certified Reference Materials for Water Analyzed by HR-ICP-MS

\begin{tabular}{|c|c|c|c|c|c|c|c|c|c|c|c|c|c|}
\hline $\begin{array}{l}\text { Ana- } \\
\text { lyte. }\end{array}$ & $\begin{array}{c}\text { Mass } \\
\text { No. }\end{array}$ & $\begin{array}{c}\text { NIST } \\
\text { 1640a CV }\end{array}$ & $\begin{array}{cc} & \text { NIST } \\
\text { V } \quad 1640 a \\
\end{array}$ & $\mathrm{SD}$ & $\%$ RSD & $\begin{array}{c}\text { NIST } \\
1643 \mathrm{e} \mathrm{C}\end{array}$ & $\begin{array}{c}\text { NIST } \\
\text { 1643e HF }\end{array}$ & $\mathrm{SD}$ & $\%$ RSD & SLRS-5 CV & SLRS-5 H & IR SD & $\% \mathrm{RSD}$ \\
\hline $\mathrm{Li}$ & 7 & 0.407 & 0.397 & 0.027 & 0.600 & 17.400 & 15.392 & 1.139 & 7.400 & 0.500 & 0.410 & 0.006 & 1.400 \\
\hline $\mathrm{Be}$ & 9 & 3.026 & 3.031 & 0.026 & 4.300 & 13.980 & 15.732 & 0.052 & 0.900 & 0.005 & 0.007 & 0.005 & 3.000 \\
\hline B & 11 & 303.100 & 334.543 & 7.013 & 3.300 & 157.900 & 183.210 & 32.428 & 17.700 & 7.460 & 10.718 & 1.669 & 4.100 \\
\hline $\mathrm{Na}$ & 23 & 3137.000 & 3209.593 & 61.957 & 4.100 & 20740.000 & 21235.763 & 770.853 & 6.300 & 5380.000 & 4985.452 & 104.694 & 2.100 \\
\hline $\mathrm{Mg}$ & 24 & 1058.600 & 1085.723 & 11.774 & 3.800 & 8037.000 & 8733.599 & 171.746 & 4.600 & 2540.000 & 2441.714 & 78.135 & 3.200 \\
\hline $\mathrm{Al}$ & 27 & 53.000 & 52.515 & 1.246 & 4.500 & 141.800 & 152.542 & 4.622 & 5.600 & 49.500 & 53.454 & 0.909 & 1.700 \\
\hline $\mathrm{Ca}$ & 44 & 5615.000 & 5685.839 & 63.769 & 4.000 & 32300.000 & 32788.455 & 657.596 & 3.500 & 10500.000 & 10796.588 & 336.574 & 3.700 \\
\hline V & 51 & 15.050 & 16.840 & 1.223 & 4.100 & 37.860 & 35.267 & 1.470 & 5.200 & 0.317 & 0.567 & 0.005 & 0.300 \\
\hline $\mathrm{Cr}$ & 52 & 40.540 & 40.635 & 1.136 & 2.400 & 20.400 & 15.506 & 0.884 & 5.700 & 0.208 & 0.264 & 0.115 & 0.500 \\
\hline Mn & 55 & 40.390 & 42.524 & 0.665 & 4.600 & 38.970 & 39.968 & 0.459 & 2.300 & 4.330 & 5.767 & 0.058 & 1.000 \\
\hline $\mathrm{Fe}$ & 57 & 36.800 & 36.603 & 1.171 & 2.800 & 98.100 & 90.023 & 0.960 & 1.600 & 91.200 & 96.433 & 0.418 & 0.900 \\
\hline Co & 59 & 20.240 & 20.373 & 0.267 & 4.800 & 27.060 & 22.730 & 0.140 & 1.100 & 0.050 & 0.065 & 0.004 & 0.600 \\
\hline $\mathrm{Ni}$ & 60 & 25.320 & 25.283 & 0.474 & 4.800 & 62.410 & 71.405 & 0.722 & 2.300 & 0.476 & 0.470 & 0.012 & 0.600 \\
\hline $\mathrm{Cu}$ & 63 & 85.750 & 85.606 & 4.749 & 4.500 & 22.760 & 18.502 & 0.074 & 0.400 & 17.400 & 18.508 & 0.278 & 1.500 \\
\hline $\mathrm{Zn}$ & 66 & NA & NA & NA & NA & 78.500 & 73.461 & 0.441 & 0.600 & 0.845 & 0.920 & 0.000 & 0.200 \\
\hline As & 75 & 8.075 & 8.098 & 0.316 & 3.800 & 60.450 & 54.450 & 0.526 & 1.300 & 0.413 & 0.551 & 0.002 & 0.200 \\
\hline $\mathrm{Se}$ & 77 & 20.130 & 20.396 & 0.558 & 3.700 & 11.970 & 13.531 & 0.649 & 3.500 & NA & NA & NA & NA \\
\hline $\mathrm{Sr}$ & 91 & 126.030 & 48.418 & 13.902 & 47.200 & 323.100 & 320.950 & 65.918 & 54.500 & 53.600 & 55.351 & 21.707 & 141.400 \\
\hline Mo & 95 & 45.600 & 46.086 & 0.821 & 4.500 & 121.400 & 133.204 & 0.442 & 0.700 & 0.500 & 0.260 & 0.005 & 2.100 \\
\hline Pd & 105 & NA & NA & NA & NA & 1.960 & 1.848 & 0.092 & 10.800 & 0.003 & 0.003 & 0.000 & 3.400 \\
\hline $\mathrm{Ag}$ & 107 & 8.081 & 9.010 & 1.878 & 6.100 & 1.062 & 1.721 & 0.216 & 5.800 & 0.010 & 0.016 & 0.003 & 10.100 \\
\hline $\mathrm{Cd}$ & 111 & 3.992 & 4.088 & 0.830 & 4.000 & 6.568 & 8.840 & 0.221 & 2.500 & 0.006 & 0.006 & 0.000 & 8.300 \\
\hline $\mathrm{Sb}$ & 121 & 5.105 & 5.222 & 0.150 & 4.500 & 58.300 & 55.991 & 0.324 & 0.900 & 0.300 & 0.314 & 0.001 & 0.400 \\
\hline $\mathrm{Te}$ & 124 & NA & NA & NA & NA & 1.090 & 0.910 & 0.015 & 7.000 & NA & NA & NA & NA \\
\hline $\mathrm{Ba}$ & 137 & 151.800 & 152.798 & 6.674 & 4.800 & 544.200 & 564.562 & 3.371 & 0.900 & 14.000 & 19.461 & 0.147 & 0.500 \\
\hline $\mathrm{Tl}$ & 205 & NA & NA & NA & NA & 7.445 & 5.276 & 0.026 & 0.500 & 0.004 & 0.005 & 0.001 & 2.400 \\
\hline $\mathrm{Pb}$ & 208 & 12.101 & 12.421 & 0.576 & 4.500 & 19.630 & 21.819 & 0.015 & 0.100 & 0.081 & 0.086 & 0.028 & 1.700 \\
\hline $\mathrm{Bi}$ & 209 & NA & NA & NA & NA & 14.090 & 16.216 & 0.020 & 0.100 & 0.001 & 0.001 & 0.000 & 1.100 \\
\hline Th & 232 & 1.619 & 1.594 & 0.001 & 4.900 & NA & NA & NA & NA & 4.011 & 2.974 & 0.175 & 5.900 \\
\hline $\mathrm{U}$ & 238 & 25.350 & 25.274 & 0.125 & 4.500 & 0.158 & 0.197 & 0.000 & 4.000 & 4.100 & 0.135 & 0.003 & 2.200 \\
\hline
\end{tabular}


geological and water reference samples. In the case of BHVO-1 and UB$\mathrm{N}$, the data obtained by both HR-ICP-MS and ICP-QMS are in good agreement for all of the REEs. The major benefits include excellent reproducibility of measurements in the wide range of elements of geological and environmental interest. Because of its high sensitivity, very diluted solutions (even up to 50,000 times) can be analyzed which minimizes the matrix effects. In addition, use of a proper internal standard, ${ }^{103} \mathrm{Rh}$, and analysis of the diluted samples helped in acquiring more precise data. Use of the NiS fire assay coupled with HR-ICP-MS was found to be very suitable for obtaining precise data for PGEs in geological samples using around $10 \mathrm{~g}$ of sample. With extremely low procedural blank values, this method was highly suitable for geological samples even at low PGE concentrations. The results presented demonstrate that HR-ICP-MS is a powerful analytical tool for the accurate and precise determination of REEs, PGEs, and several other trace elements in a variety of geological and environmental matrices. The most significant advantage is that all data required either for environmental or for geochemical (including exploration) studies can be obtained by a single instrument. In fact, using these developed procedures, precise data sets have already been generated on thousands of geological and environmental samples for several studies. This study also proves the excellent capability of rapid data acquisition for several trace elements by HR-ICP-MS which can also support groundwater studies, monitoring, and remediation efforts, in addition to hydrogeochemical studies to supplement mineral exploration efforts.

\section{ACKNOWLEDGMENT}

The authors thank the Director, CSIR-NGRI, for the support and encouragement. This work was funded by main laboratory projects MLP-6406-28 (CM). One of the authors (VB) thanks the Council of Scientific and Industrial Research (CSIR), New Delhi, India, for financial support in the form of an Emeritus Scientist Scheme.

Received August 9, 2017.

\section{REFERENCES}

1. G.A. Jenner, H.P. Longerich, S.E. Jackson and B.J. Fryer, Chem. Geol. 83(1-2), 133 (1990).

2. V. Balaram, V, Trends Anal. Chem. 15, 475 (1996).

3. I. Jarvis, M.M. Totland and K.E. Jarvis, Chem. Geol. 143(1-2), 27 (1997).

4. V. Balaram and T.G. Rao, At. Spectrosc. 24(6), 206 (2003)

5. V. Balaram, R. Mathur, V.K. Banakar, J.R. Hein, C.R.M. Rao, T.G. Rao and B. Dasaram, Indian J. Marine Sci. 35(1), 7 (2006).

6. P. Roy, V. Balaram, A. Kumar, M. Satyanarayanan, and T.G. Rao, J. Geostand. Geoanal. Res. 31(3), 261 (2007).

7. Z. Cheng, Y. Zheng, R. Mortlock and A. van Geen, Anal. Bioanal. Chem. 379, 512 (2004).

8. J.A.C. Broekaert, Analytical atomic spectrometry with flames and plasmas (Wiley-VCH Verlag GmbH \& Co. KGaA, Germany), 375 (2002)

9. P. Myers, G. Li, Yang P. and G. M. Hieftje, J. Am. Soc. Mass Spectrom. 5, 1008 (1994).

10. V. Balaram, M. Satyanarayanan, P.K. Murthy, C. Mohapatra and K.L. Prasad, MAPAN-J. Metrology Soc. India 28(2), 63 (2003).

11. G.D. Schilling, F.J. Andrade, J.H. Barnes, R.P. Sportline, M.B. Denton, C.J. Barinaga, D.W Koppenaal and G.M. Hieftje, Anal. Chem. 79, 7662 (2007).
12. M. Krachler, J. Environ. Monit. 9, 790 (2007)

13. H.E. Gabler, J. Geochem. Explor 75(1-3), 1 (2002).

14. N. Bradshaw, E. F. H. Hall and N. E. Sanderson, J. Anal. At. Spectrom. 4, 801 (1989).

15. A.J. Walder and P.A. Freedman, J. Anal. At. Spectrom. 7, 571 (1992)

16. M.R. Singh, C. Manikyamba, J. Ray, S. Ganguly, M. Santosh, A. Saha, S. Rambabu and S.S. Sawant, Ore Geol. Rev. 72(2), 1263 (2016).

17. R.R. Barefoot, J. Anal. At. Spectrom. 13(10), 1077 (1998)

18. J.C. Van Loon and R.R. Barefoot. Determination of the precious metals - selected instrumental methods (John Willey \& Sons, UK) 276 (1991).

19. V. Balaram, J. Geol. Soc. India. 72, 661 (2008).

20. P.V.D. Robert, V. E. Wyk and R. Palmer. National Institute of Metallurgy, Johannesburg, South Africa, Rep. No. 1371 (1971).

21. K.S.V. Subramanyam, V. Balaram, U.V.B. Reddy, M. Satyanarayanan, P. Roy and S.S. Sawant, MAPAN-J. Metrol. Soc. India 28(1), 1 (2013).

22. S.H. Tan and G. Horlick, J. Anal. At. Spectrom. 2, 745 (1987).

23. Z. Yu, P. Robinson, A.T. Townsend, C. Münker and A.J. Crawford, Geostds. Newsl. 24, 39 (2000).

24. O. Hanousek, M. Brunner, D. Pröfrock, J. Irrgeher and T. Prohaska, Anal. Methods 8(42), 7661 (2016).

25. I.N. Mysovskaya, E. V. Smirnova and V. I. Lozhkin, J. Anal. Chem. 6(14), 1217 (2013)

26. S.R. Taylor and S.M. McLennan. The continental crust, its composition and evolution (Blackwell Scientific Publication, Oxford, UK), 312 (1995).

27. V. Balaram, P. Roy, K.S.V. Subramanyam, L. Durai, M. Ram Mohan, M. Satyanarayanan, S. S Sawant, S.S. Kalyan Kamal and K. Vani, Indian J. Geo-Marine Sciences 44 (3), 339 (2015).

28. V. Balaram, V.K. Banakar, K.S.V. 


\section{A $_{\text {Spectroscopy }}^{\text {tomic }}$}

Subramanyam, Parijat Roy, M. Satyanarayanan, M. Ram Mohan, and S.S. Sawant, Curr. Sci. 110(11), 1334 (2012).

29. G.S. Reddi, and C.R.M. Rao, Analyst 124, 1531 (1999).

30. A.J. Naldrett and J.M. Duke, Sci. 208, 1417 (1980)

31. V. Balaram, J. Marine Geores. Geotech. 17, 17 (1999).

32. V. Balaram, J. Appl. Geochem. 14(2), 120 (2012).

33. A. Ramesh, K.R. Mohan, K. Seshaiah and N.D. Jeyakumar, Anal. Letts. 34 (2), 219 (2001)

34. M. Satyanarayanan, V. Balaram, M.S.Al Hussin, M.A.R.Al Jemaili, T.G. Rao, R. Mathur, B. Dasaram and S.L. Ramesh, India. Environ. Monit. Assessmt. 131, 117 (2007).

35. V. Balaram, V. Dharmendra, P. Roy, C. Taylor, C.T. Kamala, M. Satyanarayanan, P. Kar, K.S.V. Subramanyam, A.K. Raju and A.

Krishnaiah, At. Spectrosc. 35(2), 65 (2014)

36. C.T. Kamala, V. Balaram, V. Dharmendra, P. Roy, M. Satyanarayanan and K.S.V.Subramanyam, Environ. Monit. Assessmt. 186, 7097 (2014).

37. S. Narayanaswamy, V. Balaram, N. Ramkumar and K.V. Anjaiah, J. Geol, Soc. India 52, 301 (1998). 